\title{
Modelowanie doświadezenia kulturowego w spektaklu Teatru Chorea pt. Tehillim/Psalmy
}

\section{Wstęp}

Ciało jest naszym ogólnym sposobem posiadania świata ${ }^{1}$ stwierdza Maurice Merleau-Ponty, próbując przywrócić w ten sposób współczesnemu człowiekowi zapomnianą prawdę - nie jesteśmy w stanie przekroczyć naszej cielesnej kondycji, bo to ona osadza „ja” w świecie. Poprzez ciało zawłaszczamy świat i włączamy go do naszego jestestwa. Będąc tylko pozornie świadomymi tych mechanizmów, często „czytamy” rzeczywistość, zapominając o milczącej obecności zintegrowanego z ego pośrednika, zakamuflowanego korporalnego przedsądu. Zrewidowanie wiedzy o tym, co znajduje się pomiędzy naszą cielesnością, a tym, co już do niej nie należy, może umożliwić ponowoczesnemu człowiekowi oswojenie świata, którego - jak się wydaje - nie porządkują już żadne wielkie narracje.

Zdarzenie teatralne to specyficzna fałda rzeczywistości, rodzaj tymczasowej heterotopii ${ }^{2}$, w której ludzkie doświadczenie może zostać poddane badaniu i refleksji. Wydaje się, że współcześnie zmienia ona swoje oblicze. W centrum zainteresowania przestają znajdować się (wyabstrahowane) prawa rządzące światem, społeczeństwem lub egzystencją człowieka w ogóle. Dziś w centrum uwagi staje (fizykalne) ego.

\footnotetext{
${ }^{1}$ M. Merleau-Ponty, Fenomenologia percepcji, przeł. M. Kowalska, J. Migasiński, Warszawa 2001, s. 166.

${ }^{2}$ Heterotopia to rodzaj przeciwmiejsca, w którym wszystkie inne prawdziwe miejsca, jakie można odnaleźć $w$ kulturze, sa jednocześnie reprezentowane, kontestowane $i$ odwracane. Zob. M. Foucault, $O$ innych przestrzeniach. Heterotopie, przeł. M. Żakowski, „Kultura Popularna” nr 16/2006.
} 
Teatr zaczyna się skupiać się na samym człowieku i szukać dla niego narzędzi obcowania z otoczeniem i samym sobą. Dostrzega, że prawdziwy agon - narodziny sensu - odbywa się w zmysłowości3 i działaniu. To, co oferowane przez teatr, często nie ma już zatem charakteru nauki moralizatorskiej, prezentowania obrazów dla refleksji, raczej nie jest też zabiegiem katartycznym ani pustą stymulacją estetyczną. Wydaje się, że współczesny teatr skupia się przede wszystkim na projektowaniu możliwych do przyjęcia strategii poznawczych i akcyjnych wobec świata. Igra z przesądami, dekonstruując je i zarazem generując nowe - jako alternatywne struktury doświadczenia i doświadczania. Twórcy teatralni podejmują się, poprzez użycie różnorodnych taktyk, modelowania zarówno schematu postępowania, jak i kompetencji odbiorców ich dzieł. Artyści otwierają $\mathrm{w}$ ten sposób przestrzeń przekroczenia pozornie trwałego układu jakości tworzących wrażenie tego, co rzeczywiste - każde doświadczenie, które ledwie staje się w akcie transgresji, od razu jej podlega i uzyskuje nową jakość. Najczęściej stosowaną taktyką jest interakcja $\mathrm{z}$ odbiorcą - pobudzenie albo wręcz wymuszenie, w ramach gry, jego aktywności. Interakcja jest tutaj definiowana jako:

działanie, które występuje gdy dwa lub więcej obiektów pojmowanych jako podmioty świadome swoich działań (moment intencjonalności) wywiera na siebie obustronny wpływ, widząc w sobie nawzajem przedmioty swoich działań4.

Preferowanie taktyki interakcji w teatrze wiąże się z rozwijaniem się nowego paradygmatu świata społecznego po zwrocie performatywnym ${ }^{5}$ - kultury partycypacji ${ }^{6}$. Zmiany te są szczególnie widoczne w sferze sztuki interaktywnej, która co prawda sama rozwijała się częściowo także na gruncie szeroko pojętej sztuki performatywnej czy dramatycznej, jednak mocno stymulowana nowymi technologiami wykształciła narzędzia i język, które inspirują i mogą dziś pomóc opisać „starszą”, leżącą u jej podstaw sztukę teatru. Dzięki nim możliwe jest określenie wstępnych ram danej sytuacji teatralnej.

3 M. Merleau-Ponty, dz. cyt., s. 237.

4 Por: R. Kluszczyński, Sztuka interaktywna. Od dzieta-instrumentu do interaktywnego spektaklu, Warszawa 2010, s. 176.

5 Zob. E. Domańska, Zwrot performatywny we wspótczesnej humanistyce, „Teksty Drugie" nr 5/2007, s. 52.

${ }^{6}$ Zob. R. Kluszczyński, dz. cyt., s. 120.

7 Zob. tamże, s.77-97. 


\section{Modelowanie doświadczenia w spektaklu Tehillim/Psalmy}

Przykładem praktyk teatralnych, w których grę z doświadczeniem i kompetencją odbiorcy można uznać za zasadę twórczą, jest spektakl Stowarzyszenia Teatralnego Chorea w reżyserii Pawła Passiniego Tehillim/Psalmy ${ }^{8}$. W tym wydarzeniu, działania aktorów połączone są nieoczywistą paralelą z działaniami odbiorców, jako jego świadków. W efekcie (poznawcza) aktywność uczestników jest specyficznie modelowana.

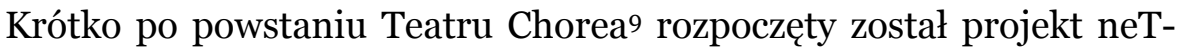
Theater - Teatr w Sieci Powiązań, zainicjowany przez Pawła Passiniego - absolwenta reżyserii Akademii Teatralnej w Warszawie. Podstawową ideą neTTheater jest wykorzystanie nowoczesnych form komunikowania dla eksploracji sfery interaktywności teatru, a także stworzenia nowego języka artystycznego nawiązującego do formy nowych mediów. Podejmowana jest zarazem próba zrozumienia kondycji współczesnego człowieka uwikłanego w gąszcz znaków i komunikatów ${ }^{10}$. Zawierają się w niej także początki spektaklu Tehillim/Psalmy. Spektakl to:

współczesne, radykalne odczytanie tekstu Psalmów przez pryzmat dokonań największych buntowników XX wieku - Antoina Artauda, Francisa Bacona, Witolda Gombrowicza. To terapia kultury, przywracanie pamięci, rehabilitacja wrażliwości ${ }^{11}$.

Owy cytat niejako streszcza złożony proces, jakiemu poddany zostaje widz/uczestnik spektaklu, poprzez zastosowanie przez twórców specyficznych zabiegów formalnych.

W spektaklu Pawła Passiniego Tehillim/Psalmy, zgodnie z przedstawioną hipotezą, podjęta została próba projekcji na doświadczenie odbiorcy nowego schematu obcowania z przedmiotami i procesami społecznokulturowymi. W centrum struktury spektaklu umieszczone zostały specyficzne artefakty kulturowe zorganizowane tak, by stać się osnową interakcji społecznej, a więc zmuszać odbiorcę do przyjęcia konkretnej emocjonalnej i duchowej postawy wobec tego, co widzi, słyszy, czyta i, należy to dodać, odczuwa. Trzecią stroną w tej dialektycznej komunika-

8 Premiera spektaklu odbyła się 14 czerwca 2008 r. w Łodzi.

9 Etapy rozwoju grupy, metodyka i estetyka pracy artystów zebrana jest w katalogu wydanym z okazji wydarzenia RETRO/PER/SPEKTYWY Chorea. Festiwal Teatralny. Łódź 2010. Teatr Chorea. Pierwsze sześć lat, red. M. Jabłońska, Łódź 2010.

${ }^{10}$ Zob. tamże, s. 98.

${ }^{11}$ Tamże, s. 82. 
cji jest Inny - uczestnik lub performer. Podstawą struktury spektaklu Passiniego są Psalmy, teksty - pieśni, stanowiące dzisiaj przecięcie i punkt zborny dla katolików, protestantów, wyznawców prawosławia i Żydów ${ }^{12}$. W przedstawieniu podjęta jest próba przywrócenia ich kulturze, jako ciągle żywej struktury performatywnej, która jednak wydaje się być dziś marginalizowana. Artyści Teatru Chorea i neTTheater podejmują zatem próbę ustanowienia - wymodelowania nowej strategii obcowania z Psalmami:

Teatr w Sieci Powiązań [neTTheater - przyp. autora] przedstawia, ujawnia, przywraca niemal zupełnie zapomnianą tradycję śpiewania w pustce. Psalmy - pieśń początków, pieśń podróży, źródło poezji jak najbardziej ludzkiej, ale natchnionej; zarodek, podstawowa komórka - DNA kultury, DNA teatruํㅜ․

Spektakl zaplanowany jest więc jako proces transgresji aktualnej przestrzeni $\mathrm{w}-\mathrm{z}$ jednej strony - pozaczasowy, mitologiczny czy też rytualny moment śpiewania Psalmu, a z drugiej w konkretną przestrzeń i czas, w jakich Psalmy śpiewał król Dawid i jemu współcześni. Przeniesienie to z kolei otwiera przestrzeń dla kondycji człowieka, która może przekroczyć jednostkowość ku tymczasowej wspólnotowości śpiewających. Wreszcie, powstawanie dzieła poprzez interakcję uczestników z jego dyspozytywem ${ }^{14}$, jest momentem przemiany odbiorcy w twórcę.

W sposób rzeczywisty, widz wraz z performerami udaje się w podróż. Przedstawienie realizowane było $\mathrm{w}$ przestrzeniach o silnej redundancji znaczeniowej, takich jak świątynie lub w miejscach znaczeniowo otwartych, w Łodzi taką lokalizacją były budynki zamkniętej fabryki tekstylnej ${ }^{15}$. Wchodzący w tę przestrzeń widzowie spektaklu są zrazu wciągani przez grupę aktorów w wąskie przejście, tam wykonują oni w ciszy choreografię składającą się $\mathrm{z}$ bardzo określonych, metonimicznych gestów. Nagle uciekają i widzowie podążają za nimi, trafiając do pomieszczenia, gdzie ta sama grupa wykonuje w kręgu chóralnie pieśń. Kolejnym

12 Tamże.

13 Tamże.

14 Wykorzystuję tutaj termin zaczerpnięty z pracy Ryszarda Kluszczyńskiego, którym posługuje się on w przypadku sztuki interaktywnej. Dyspozytyw to niejako kontekst dla doświadczenia odbiorcy. Kluszczyński zakłada, że twórca jest swego rodzaju designerem, który projektuje pole (kontekst) dla twórczej aktywności odbiorcy. Jednak nie wszystkie składniki dyspozytywu są zależne od twórcy. Poza wpływem artysty pozostają np. czynniki społeczno-kulturowe, które przedostają się do dyspozytywu wraz z innymi, celowo dobieranymi elementami. Ich źródłem są doświadczenia kulturowe odbiorców, ale także, nie zawsze uświadamiany, kontekst twórczości artysty. Zob. R. Kluszczyńsiki, dz. cyt., s. $132-133 ; 185$.

${ }^{15} \mathrm{~W}$ tej przestrzeni w spektaklu uczestniczył autor pracy $-\mathrm{T}$. C. 
momentem zatrzymania w podróży jest scena, w której aktor z megafonem i telefonem w ręku prowadzi intymną, choć jednostronną, ale wciąż konwersację z Bogiem. Postać/aktor jest osamotniony, żąda lub prosi Boga o kontakt. Stamtąd widzowie prowadzeni są do kolejnej sali, w której aktorzy, tym razem nie w kręgu lecz stojący w rzędzie i zwróceni do okien, słuchają muzyki trąbek, by na koniec wykonać pieśń/modlitwę i przejść do kolejnego dużego pomieszczenia. Tam okazuje się, że te same gesty, które widzieli na początku, wykonywali także inni. Pokazywane są również wtedy projekcje wykonania choreografii na ulicach, z uczniami szkoły baletowej i w kościele. Po chwili spędzonej w miejscu, gdzie przy dźwiękach muzyki wyświetlane są fragmenty Psalmów, uczestnicy wydarzenia prowadzeni są do sali teatralnej, tam odbywa się pozostała część spektaklu. W jej trakcie każdy performer niejako mierzy się i zarazem prezentuje Psalm, który sam sobie wybrał i jest mu przypisany.

Pierwszym zakresem dyspozytywu spektaklu jest więc poruszanie się w (labiryntowej) przestrzeni. Jest to paralelą do opisanej w Biblii nomadycznej wędrówki Izraelitów, a przez to przywołaniem narracji wyrzucenia z domów i wędrówki do „ziemi obiecanej”. Można powiedzieć, że poprzez dyspozytyw spektaklu przedstawiana jest mityczna droga Izraelitów. Wewnątrz tego performansu, jako jego świadek, znajduje się widz. Spektakl otwiera go w ten sposób na nową, własną wędrówkę, Zmusza i uczy odbiorcę (w sensie symbolicznym), jak obchodzić się z elementami systemu kulturowego, rozumianymi nie tyle jako historyczne artefakty, ale faktyczne cząstki ludzkiej tożsamości. Każde zatrzymanie w wędrówce to ewokacja innej sytuacji i konfiguracji społecznej, w każdej odbiorca musi się odnaleźć, ustanowić wobec intymnej (bo w ogromnej otwartej przestrzeni - pustce - stajemy się bezbronni i odsłonięci) obecności Innego, która sama w sobie staje się warunkiem wymuszającym konfrontację. W sposób bardzo fizyczny pojawia się doświadczenie wspólnotowości. Widzowie muszą nauczyć się być grupą, zlokalizować się nawzajem i podzielić (nie zawsze w pełni otwartą) przestrzenią. Przywołana zostaje wolicjonalność zdarzenia teatralnego, wyeksponowana stawia uczestników wydarzenia przed wyborem - jeśli nie podejmą wspólnie trudu udziału w performansie, to ten może się nie powieść. Uczestnicy poddani są więc działaniu, które powinno być rozumiane jako rodzaj przemocy symbolicznej. Za jej pomocą może następować wielopoziomowe modelowanie aktywności odbiorcy: jego kompetencje wyznaczane są przez formułę spektaklu, wymuszającą podjęcie działania, dla którego automatycznie wzorem stają się działania performerów. Transgresywną przestrzeń tego procesu wyznacza przekraczanie struktury teatralnej na rzecz społecznej - model działania wewnątrz spektaklu może być wzorem aktualizowanym $\mathrm{w}$ życiu codziennym oraz $\mathrm{w}$ procesach poznawczych 
i tożsamościowych - jako modelowanie sposobu dokonywania refleksji i interpretowania świata zewnętrznego.

Mimo wspólnotowego działania, właśnie sfera jednostkowości jest szczególnie wyeksponowana w spektaklu. Choreografia, którą wykonują aktorzy, jest $\mathrm{w}$ istocie zestawem gestów inspirowanych literami alfabetu hebrajskiego. Performerzy próbują/uczą czynić albo wywoływać psalm ciałem, odnosząc się jednocześnie do własnej (choć osadzonej we wspólnotowej) historii i tożsamości. W zrozumieniu tego działania może pomóc rozumienie ciała i historii zaproponowane przez Merleau-Ponty'ego:

Rolę ciała w pamięci można zrozumieć tylko pod warunkiem, że pamięć nie jest konstytuującą świadomością przeszłości, lecz wysiłkiem otwierania na nowo czasu dzięki implikacjom zawartym w teraźniejszości, i że ciało, będące naszym stałym sposobem „zajmowania postaw” i w ten sposób tworzenia przedmiotów pseudopodobnych, jest sposobem naszego obcowania zarówno z czasem, jak z przestrzenią ${ }^{16}$.

Podsumowując, ciało jest podstawowym narzędziem ewokowania przeszłości, jej aktualizacją przez projektowanie na teraźniejsze działania. Wykorzystując ten mechanizm twórcy spektaklu czynią jego strukturę matrycą dla rekonstrukcji Psalmów, jako znaczącego tekstu kulturowego.

Obserwując w jednej z końcowych scen tańczących aktorów, reżyser powtarza przez mikrofon „Każdy tańczy sam!” - nie wiadomo czy jest to komentarz do tego co widzi, czy też wydaje polecenia. Jego celem nie jest chyba jednak zwerbalizowanie i podkreślenie alienacji jednostki, tym bardziej, że większość Psalmów aktorzy wykonują razem. Indywidualizacja postaci ma, jak można sądzić, inne znaczenie i związana jest z modelowaniem w tym działaniu specyficznego doświadczenia jednostkowości, zarówno wewnątrz spektaklu, jak i w modusie społecznym. Bardzo bliska temu działaniu jest filozofia włoskiego myśliciel Giorgio Agambena, opisująca nowe porządki wspólnotowe. Postuluje on istnienie bytu „jakiegokolwiek” ${ }^{17}$, które to określenie odsyła do pojedynczości niedefiniowanej przez żadne właściwości, a zwłaszcza przez żadne atrybuty, które miałyby wyznaczać jej przynależność do danej wspólnoty ${ }^{18}$. Częściowo unieważnia on zatem dylemat konieczności wyboru między wyjątkowością a ogólnością - a na płaszczyźnie społecznej między tym, co indywidualne, a tym, co wspólnotowe. Byt ,jakikolwiek” powstaje przez:

\footnotetext{
${ }^{16}$ M. Merleau-Ponty, dz. cyt., s. 202.

${ }^{17}$ G. Agamben, Wspólnota, która nadchodzi, przeł. S. Królak, Warszawa 2008, s. 7.

${ }^{18}$ R. Kluszczyńsi, dz. cyt., s. 156.
} 
[...] niezróżnicowanie, tego co wspólne, i tego, co właściwe, rodzaju i gatunku, istoty i przypadłości. [...] [Jak dzieje się to w spektaklu,] przejście od możności do aktu, od wspólnej formy do pojedynczości, nie jest wydarzeniem dokonanym raz na zawsze, lecz nieskończonym szeregiem modalnych oscylacji ${ }^{19}$.

Relacje między nimi są płynne i nieostateczne, to, co wspólne, i to, co indywidualne, wymieniają się stale miejscami i funkcjami, są jedynie aspektami bytu jakiegokolwiek $^{20}$.

W tej perspektywie tożsamość nie jest wyalienowaną kreacją, lecz ewokacją, przybliżeniem się do jednej z wielu możliwości/idei ${ }^{21}$. Na ten temat analogicznie wypowiada się Merleau-Ponty, stwierdza, że

człowiek jest ideą historyczną [...], ludzka egzystencja niczego nie posiada w sposób bezwarunkowy, a jednak nie ma również żadnego atrybutu przypadkowego ${ }^{22}$.

Każdy performer ma swój wybrany Psalm, numer jego Psalmu nosi na koszulce niczym zawodnik. Swoim ciałem przywołuje on ideę tej pieśni i czyni ją częścią własnej tożsamości. Performer generuje swoją jednostkowość, jednocześnie nigdy nie wykraczając ze wspólnotowego lub czyniąc je nieodróżnialnym. Czyni to wykonując „swój” Psalm, ale także ucząc się gestów „należących” do innego aktora. Proces ten ma charakter społecznej wymiany ${ }^{23}$. W oscylację między wspólnotowością a jednostkowością wprowadzeni są także widzowie, którzy - podążając za performerami - uczestniczą w „wibrującym” procesie wyłaniania i rozmywania się tożsamości. Odmiennym problemem jest wprowadzenie przez Passiniego do spektaklu obrazów nieudanych rewolucji i protestów społecznych, pochodzących przede wszystkim z najnowszej historii komunistycznych Chin. Potwierdza on $\mathrm{w}$ ten sposób ambicję wpływania na pozateatralną rzeczywistość, ale zarazem czyni gest zwątpienia we wspólnotę ludzką.

W spektaklu Tehillim/Psalmy modelowana jest także postawa spoleczna, którą Foucault nazywa paresią. W swym historycznym znaczeniu jest to mówienie prawdy ponad obywatelstwem, sytuacja, w jakiej osoba nie mająca żadnych praw - nie będąca obywatelem polis - staje naprzeciw tyrana i krytykuje go, będąc przy tym głęboko przekonaną o swojej racji ${ }^{24}$. Jest to rodzaj performansu, który jednak nie rządzi się warunkami

19 G. Agamben, dz. cyt., s. 25-26.

${ }^{20}$ R. Kluszczyński, dz. cyt., s. 157.

${ }^{21}$ Tamże, s. 73.

${ }^{22}$ M. Merleau-Ponty, dz. cyt., s. 191.

${ }^{23} \mathrm{~W}$ końcowej fazie projektu choreografia miała być wykonana na jednym z warszawskich placów przez kilkaset osób.

$24 \mathrm{Na}$ temat paresi u Michela Foucaulta wypowiadał się Paweł Mościski podczas wykładu w Instytucie im. J. Grotowskiego we Wrocławiu 6.05.2011 r. 
fortunności 25 , bo osoba wypowiadająca się nie ma żadnej instytucjonalnej ani społecznej legitymizacji dla takiego postępowania. Można powiedzieć, że performans taki jest fortunny jedynie wtedy, gdy osoba taka przeżywa. $\mathrm{Z}$ performansu wyróżnia paresię także fakt intymnego stosunku do sytuacji, a także głębokie przekonanie o wypowiadaniu osobistej prawdy. Bliskie jest to performansowi tożsamościowemu, jak opisuje go Judith Butler ${ }^{26}$.

Performerzy Psalmów nie mówią prawdy, przynajmniej w bezpośrednim tego słowa znaczeniu. Grają postaci, które w pewnym rejestrze posługują się paresią. Ich akt wygłoszenia Psalmu - śpiew w pustce ${ }^{27}$ - jest zwerbalizowaniem tak rozumianej prawdy w wierze w nią. Każdy staje $\mathrm{w}$ samotności przed tyranią panoptycznej władzy społeczeństwa ${ }^{28}$ i nie uginając się pod jej wzrokiem wypowiada swoją prawdę. Taka postawa w zamyśle Passiniego okazuje się jedyną skuteczną i dającą wolność. Uczestnicy spektaklu są do niej „przyuczani” przez bycie świadkami działań i uczestniczenie w interakcji. Pozornie nie wykracza to poza „zwykłe” doświadczenie teatralne, jednak przez odpowiednią strukturę narracyjną i przestrzenną spektaklu granica między tym, co jednostkowe, a tym, co wspólnotowe zostaje przesunięta ku temu drugiemu, przez to możliwe jest odczucie paresii performera jako własnej.

\section{Podsumowanie}

Na gruncie fenomenologii percepcji Maurice Merleau-Ponty wielokrotnie podkreśla: „Problem świata, a na początek problem ciała własnego, polega na tym, że wszystko się w nim zawiera” ${ }^{29}$. Być może właśnie istotowe współistnienie ciała i świata przez nie doświadczanego utrudnia dostrzeżenie znaczenia tego pierwszego, a co za tym idzie, niezrozumienie mechanizmów rządzących nie tylko poznaniem, ale także tworzeniem i komunikowaniem sensu.

25 Zob. E. Fischer-Lichte, Estetyka performatywności, przeł. M. Borowski, M. Sugiera, Kraków 2008, s. 33.

${ }^{26}$ Zob. J. Butler, Zapisy na ciele, performatywna wywrotowość, przeł. I. Kurz, [w:] Antropologia widowisk, red. L. Kolankiewicz, Warszawa 2005, s. 585-596.

27 Teatr Chorea..., s. 82.

${ }_{28}$ M. Foucault, Nadzorować i karać. Narodziny więzienia, przeł. T. Komendant, Warszawa 1993, s. 241-242.

${ }^{29}$ M. Merleau-Ponty, dz. cyt., s. 219. 
Zawsze dostrzegano, że gest lub mowa przeobrażają ciało, ale poprzestawano na stwierdzeniu, że stanowią one rozwinięcie lub przejaw innej mocy, myśli lub duszy. Nie widziano tego, że aby móc wyrażać, ciało musi w ostatecznej instancji stać się myślą lub intencją, którą dla nas znaczy3o.

Jednocześnie:

[...] niezależnie od tego, czy chodzi o ciało innego, czy o moje własne ciało, jedynym sposobem poznania ludzkiego ciała jest jego przeżywanie, to znaczy przejmowanie na własne konto dramatu, który je przenika, i jednoczenie się z nim³1.

W związku z powyższym, można przyjąć, że wbrew tradycji kartezjańskiej, niemożliwe jest ustanowienie „ja” jako zdystansowanego podmiotu. Świadomość istnieje w ciele, nie jest samą tylko myślą, stąd niemożliwe jest traktowanie ciała jako odrębnego przedmiotu. Jednocześnie, ciało wiecznie oddaje swoją tożsamość na rzecz poznawanego otoczenia. Wynikająca z tego oscylacja ciała między „ja” a otoczeniem jest zarazem kanałem, miejscem i sposobem zachodzącej między nimi komunikacji. Możliwe jest jej obserwowanie i badanie, bo sens ujawnia się tutaj w fizycznej ekspresji. Procesy te są jednak nieskończenie skomplikowane.

Wiedza, i być może także artystyczna intuicja, którą posiadają twórcy teatralni, wystarczy jednak do podejmowania przez nich prób takiego kreowania zdarzenia teatralnego, by wpływać bezpośrednio na ciało uczestników zdarzenia teatralnego, a przez to na komunikację jaka zachodzi między odbiorcą i światem w ogóle. Twórcy nie tyle tworzą „inną” rzeczywistość na oczach widzów, co raczej modelują przestrzeń pomiędzy uczestnikami, przestrzeń ich współistnienia.

W perspektywie powyższych rozważań w nowym świetle jawi się liminoidalna koncepcja teatru Victora Turnera ${ }^{32}$. Opisując zjawiska progowe zarówno w kulturach prostych, jak i złożonych, postindustrialnych społeczeństw, Turner umieszcza je systemowo w dyskursie społecznym. To, czy fenomen jest liminalny lub liminoidalny, określa jego strukturalna relacja do całego systemu społecznego, szczególnie w zakresie atrybucji czasu i przestrzeni jako należących do sfery pracy lub czasu wolnego 33 . Podobnie określone zostają sztuki performatywne. Liminoidalny charakter teatru przejawia się także w jego „liminalnym rodowodzie": historycznym związku z rytuałami przejścia; działaniu

30 Tamże, s. 218.

${ }^{31}$ Tamże, s. 219.

${ }^{2}$ Zob. V. Turner, Od liminalności do liminoidalności $w$ zabawie, przeptywie i rytuale. Szkic z symbologii komparatywnej, [w:] tegoż, Od rytuału do teatru, przeł. M. i J. Dziekan, Warszawa 2005.

33 Zob. tamże, s. 54-55. 
w sferze czasu wolnego; względnie kolektywnym charakterem w paradoksalnym połączeniu z tendencją do eksponowania jednostki (np. indywidualność aktora a kolektywność widowni); twórczym - zindywidualizowanym sposobie działania (wysokie wartościowanie innowacyjności); fakultatywności udziału członków społeczności w wydarzeniach teatralnych; sfunkcjonalizowaniu sztuki dramatycznej jako środka refleksji i krytyki społecznej34. Wreszcie, zasadniczym warunkiem wskazującym na teatr jako gatunek liminoidalny. jest zawieszenie normatywnej struktury społecznej, które czyni ze sztuki performatywnej sferę eksperymentowania, generowania nowych elementów i ich nowych zestawień35. To właśnie stanowi o wartości kulturowej zjawisk takich jak teatr.

Tworzenie i podtrzymywanie warunków sprzyjających pojawianiu się innowacji w systemie kulturowym, jednocześnie na poziomie makro - całych struktur społecznych, jak i mikro, a w tym resemiozie systemów znaków, świadczy o wyjątkowym potencjale mediacyjnym i komunikacyjnym liminalności. O ile jednak $\mathrm{w}$ zaproponowanej przez Turnera perspektywie, wyeksponowane jest systemowe i dyskursywne działanie procesów „progowych”, o tyle przytoczone przykłady wskazują na bardziej podmiotowe podstawy ich działania. Merleau-Ponty opisuje ciało jako swego rodzaju przestrzeń realizacji (stawania się bytu ze wszystkimi jego jakościami):

Tożsamość rzeczy w ciągu doświadczenia percepcyjnego jest tylko innym aspektem tożsamości ciała własnego $\mathrm{w}$ trakcie ruchów, za pomocą których badam rzecz; o b i e tożs a mości są te go s a m e go rodzaju [...] Zapuszczam się z moim ciałem pośród rzeczy, które współistnieją ze mną jako podmiotem wcielonym, i to życie w rzeczach nie ma nic wspólnego z konstruowaniem przedmiotów naukowych. Podobnie gesty innego człowieka rozumiem nie przez akt intelektualnej interpretacji, bo komunikowanie się różnych świadomości nie tylko opiera się na wspólnym sensie ich doświadczeń, ale również ten sens ugruntowuje ${ }^{36}$.

Ciało, rozumiane nie tylko fizycznie, ale także jako zespół procesów życiowych dążących do utrzymania homeostazy (rozumianej jako dynamiczna równowaga jego aktywności), jest miejscem i materią ciągłej oscylacji między rzeczywistościami. Nigdy nie jest ani tylko „ja”, ani tylko „nie-ja”. Jako byt ambiwalentny jest ciało zatem par excellence liminalne, bo to $\mathrm{w}$ nim zachodzi proces wymiany, umożliwiający przeniesienie sensu. Jego negocjacja nie zachodzi pomiędzy, ale dokładnie „w progu”, w którym realizują się obie komunikujące realności.

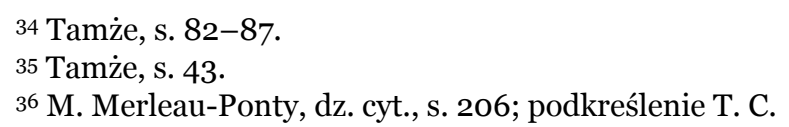


Skoro ciało zawsze jest „ośrodkiem” istnienia i komunikacji, to na czym polega jego specyficzna kondycja w teatrze? Teatr tworzy wyjątkowe, „reaktywne” 37 środowisko, w którym następuje modelowanie doświadczenia widza - renegocjacja latentnych schematów poznawczych, czyli przedsądów. W spektaklu Tehillim/Psalmy budowane jest raczej doświadczenie wspólnotowe aniżeli jednostkowe - rekonstrukcji podlega tożsamość grupowa, a nie indywidualna. Można jednak sobie wyobrazić, że procesy te przebiegają na o wiele głębszych poziomach indywidualnej świadomości. Ich opisanie wydaje się jednak nie być jeszcze w zasięgu dostępnej nam metodologii.

\section{Bibliografia}

Agamben Giorgio, Wspólnota, która nadchodzi, przeł. S. Królak, Sic!, Warszawa 2008. Butler Judith, Zapisy na ciele, performatywna wywrotowość, przeł. I. Kurz, [w:] Antropologia widowisk, red. L. Kolankiewicz, Wydawnictwo Uniwersytetu Warszawskiego, Warszawa 2005.

Domańska Ewa, Zwrot performatywny we wspótczesnej humanistyce, [w:] „Teksty Drugie" nr 5/2007.

Fischer-Lichte Erika, Estetyka performatywności, przeł. M. Borowski, M. Sugiera, Księgarnia Akademicka, Kraków 2008.

Foucault Michel, Nadzorować i karać. Narodziny więzienia, przeł. T. Komendant, Fundacja Aletheia, Warszawa 1993.

Foucault Michel, $O$ innych przestrzeniach. Heterotopie, przeł. M. Żakowski, „Kultura Popularna" nr 16/2006.

Grotowski Jerzy, Teksty z lat 1965-1969, wyb. J. Degler, Z. Osiński, Wydawnictwo Centralnego Programu Badań Podstawowych, Wrocław 1990.

Kluszczyński Ryszard, Sztuka interaktywna. Od dzieła-instrumentu do interaktywnego spektaklu, WAiP, Warszawa 2010.

Merleau-Ponty Maurice, Fenomenologia percepcji, przeł. M. Kowalska, J. Migasiński, Unus, Warszawa 2001.

Schechner Richard, Przyszłość rytuału, przeł. T. Kubikowski, Volumen, Warszawa 2000.

Teatr Chorea. Pierwsze sześć lat, red. M. Jabłońska, Stowarzyszenie Teatralne „Chorea”, Łódź 2010.

Turner Victor, Od rytuału do teatru, przeł. M. i J. Dziekan, Volumen, Warszawa 2005. van Gennep Arnold, Obrzędy przejścia, przeł. B. Biały, PIW, Warszawa 2006.

37 R. Kluszczyński, dz. cyt., s. 93. 